\title{
Übersicht über die referierten Zeitschriften
}

Unter Zeitschriften sind nicht nur alle periodisch erscheinenden Schriften verstanden, sondern im weiteren Sinne auch alle zwanglos erscheinenden Veröffentlichungen von Sternwarten, Instituten und Gesellschaften.

Die durchgesehenen Zeitschriften sind in den folgenden Abschnitten IV-V zusammengestellt.

Einzelne Zeitschriftennummern, die nicht direkt eingesehen werden konnten, sind durch einen Stern $\left({ }^{*}\right)$ kenntlich gemacht.

Die im Astronomischen Jahresbericht angewandten Abkürzungen sind in den Abschnitten I-III gegeben.

\section{Allgemeine Abkürzungen}

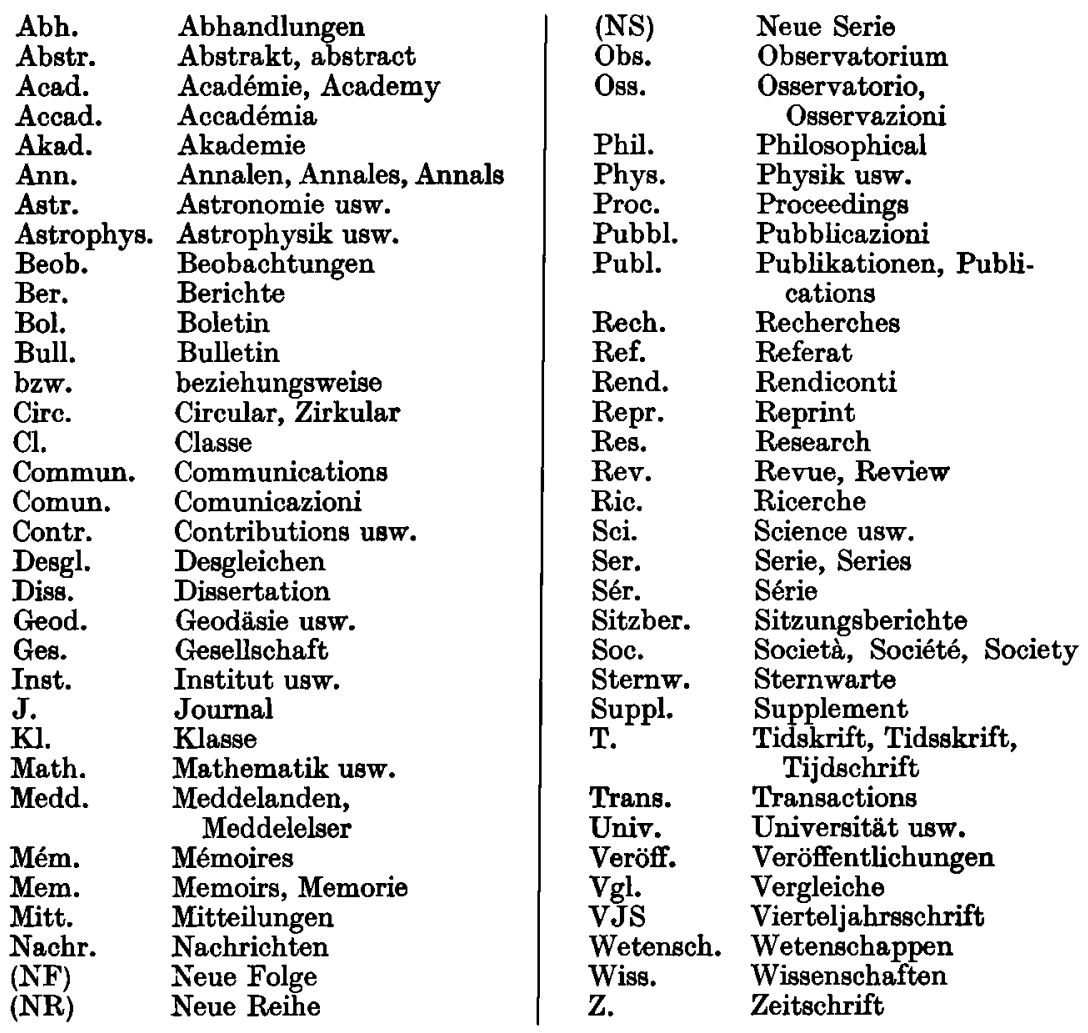

